焉 床 亜急性甲状腺炎に心内膜下梗塞を併発した 2 例

\begin{tabular}{lrrrrr}
\multicolumn{5}{c}{ 三重大学医学部第一内科 } & \\
安田 & 正樹 & 武内 & 操 & 近藤 & 正士 \\
藤井昌麻呂 & 小西 & 得司 & 須川 & 正宏 \\
浜田 & 正行 & 中野 & 趃 & 竹沢 & 英郎
\end{tabular}

\title{
TWO CASES OF SUBENDOCARDIAL INFARCTION ASSOCIATED WITH SUBACUTE THYROIDITIS
}

\author{
Masaki Yasuda, MD, Misao TaKeuchI, MD, Masashi Kondo, MD, \\ Masamaro FujI, MD, Tokuji KonishI, MD, Masahiro Sugawa, MD, \\ Masayuki HAMADA, MD, Takeshi NAKANO, MD \\ and Hideo Takezawa, MD,
}

The First Department of Internal Medicine, Mie

University School of Medicine, Tsu

\begin{abstract}
概要 我々は，亜急性甲状腺炎に心内膜下梗塞を併発した 2 例を経験した。症状は，57才女性 および50才男性で, 共に感冒様症状にて発症し, 頻脈, 頝部痛, 強い资症所見を呈し， $T_{3} \cdot T_{4}$ 高値, ${ }^{131} \mathrm{I}$ および ${ }^{123} \mathrm{I}$ 甲状腺シンチによる24時間摂取率低值等の甲状腺㙨能検查と併せて亜急性 甲状腺炎と診断され，同時に胸痛発作を来し，血中醭素上昇，心電図变化等から，心内膜下梗 塞と診断された。左室造影では, 2 例共に下壁のakinesisを, 又, 冠動脈造影では, 重症な硬化 性病变を示した。我々の症例では, これら冠動脈硬化性病変の存在に加克て, 覀急性甲状腺炎 による急激な血行動態の変化も，心筋梗塞発症の最も大きな要因の一つとなつたと考克られた。 甲状腺ホルモンは，心筋に対し，直接的なinotropic, chronotropic effectと二次的な交感神経系 の機能六進作用をもつが，その機序は明らかでない，しかし，これらの作用には， $\beta$ 受容体庶断 薬は, 実験的にも臨床的にも効果が認められる所であり，我々の症例においても著効を示した。
\end{abstract}

\section{緒 言}

亜急性甲状腺炎は，1904年De Quervainにより 記載されて以来, 最近では必ずしもまれでなく， 多数例での臨床的検討，或いは治療効果の検討に 対する報告も認められるようになつた。

本症では，その急性期に大量の甲状腺ホルモン が血中に流入するために, 種々の循環器症状を呈 する、しかしながら，本症に急性心笳梗塞を併発 したといら報告は，我々の調べた限りでは見当ら ない，我々は，亜急性甲状腺炎に急性心内膜下梗 塞を併発した 2 例を経験したので報告する。

[昭和58年11月 28 日受稿]

\section{症例}

症例 1：57才，女泩, 主婦.

主訴：前胸部痛。

家族歴：特記すべき事なし．

既往歴：10年前より高血圧，糖尿病を指摘さ れている。 2 年前に胆石症にて，胆のう摘出術を 受けた。

現病歴： 3 年前上り年 $2-3$ 回の労作時前胸 部痛めり, 昭和 57 年 2 月初めより, 動悸拉よび $38^{\circ} \mathrm{C}$ の発熱，咽頭痛の感冒様症状に続いて，同18日に は安静時に䄪30分持続する前胸部痛を認め，2 月 19日急性心筋梗塞の疑いで入院した。

入院時所見：体温 $38.6^{\circ} \mathrm{C}$ ，脈拍 $114 /$ 分整，血 王140/86mmHg，甲状腺右葉に硬結を触知し，同 
表 1 。症例 1 。 と症例 2 , の入院時検査成績

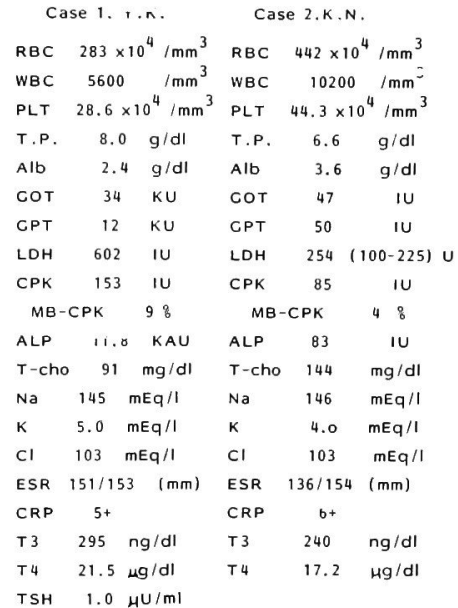

部に圧痛を認めた。頝静脈怒張なく，心音では， III音 IV音を聴取，肺にラ音を認めず，腹部は平 坦・軟, 肝脾腫なく, 四肢に浮腫なし、表在リン パ節触知せず，神経学的にも異常所見を認めなか つた。

入院時検査所見：表 1 のように, 白血球数 $5600 / \mathrm{mm}^{3}$ 之正常, LDH 602 単位, CPK 153単位 と高値を示した。血沈は 1 時間値 $151 \mathrm{~mm} ， 2$ 時間 值 $153 \mathrm{~mm}$ と亢進, CRPも5 +と強陽性を示した。 甲状腺機能検查では， $\mathrm{T}_{3} 2.95 \mathrm{ng} / \mathrm{dl}-\mathrm{T}_{4} 21.5 \mu \mathrm{g} /$ $\mathrm{dl}$ と上昇し, $\mathrm{TSH} 1.0 \mu \mathrm{U} / \mathrm{ml}$ 以下と低値を示し た。胸部 X線像では, 心陰影の左 4 弓の突出が認 められた。心電図では，図 1 に示すように，入院 時，洞性頻脈，II, III-aVF, $V_{1} \sim V_{6}$ でST低下が認 められ，第 6 病日には，II, III aVFで冠性 T波が 出現した。

入院後の経過：CCUに收容し, Swan-Ganz力 テーテル検査を施行したところ, 肺動脈圧35/ $16(\overline{27}) \mathrm{mmHg}$, 肺動脈契入王 $\overline{20} \mathrm{mmHg}$, 右房圧 $\overline{4} \mathrm{mmHg}$, 心係数 3.82 と Forrester subset IIを示し た。酸素, 利尿薬, isosorbide dinitrate（以下 ISDN)を投与し，心不全は改善，さらに，図 2 の よ5に第 4 病日より, propranolol 30mg/日を投 与. 第 6 病日以後, 胸痛, 頻脈改善, 酵素も正 常化し,第20病日には炎症所見もほぼ正常化した。

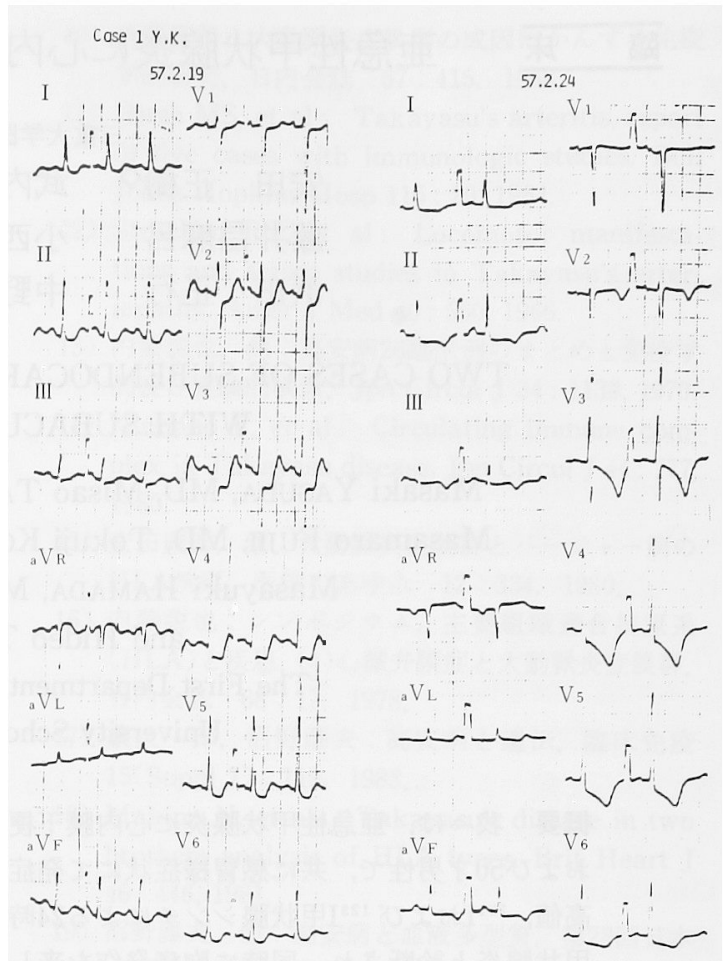

図 1. 症例 1 の心電図変化

又，第 20 病日の甲状腺 ${ }^{131}$ I摄取率は $3 \%$ と低下し ていたが，第34病日には34\%と正常化した。

約 2 力月後に施行した, 左室造影 (図 3 ) では, Segment (以下Seg.) 5, Seg. 7がakinesisであり， Sellers分類 I 度の僧帽弁逆流を認めた。同時に行 なつた冠動脈造影（図 4 ）では，左冠動脈主幹部 に約 $50 \%$ の狭窄を認め，さらに，左前下行枝Seg. 9，回旋枝Seg. 11，13，拈よび右冠動脈Seg. 2に約 90\%の狭窄を認めた。

症例 2５0才，男性, 医師.

主訴：胸部絞扼感, 咽頭痛.

家族歴：祖父母－父が高血圧。

既往歴：20才頃，高血圧を指摘されたが放置 していた。

現病歷：昭和57年10月19日前胸部から後頭部 へ放散する絞扼感出現，冷汗を伴い，30分間の安 静にて消失した。その後同様の発作が 5 日間で 3 回あり，入院数日前より咽頭痛・易疲労感を訴え， 10月26日近医より当科入紹介され入院した。 


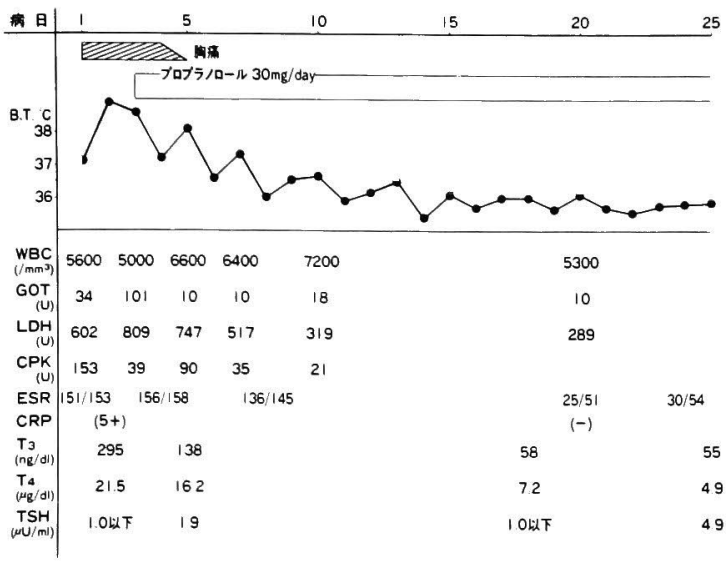

図 2, 症例 1 。臨床経過および㭘査所見

Case 1 Y.K.

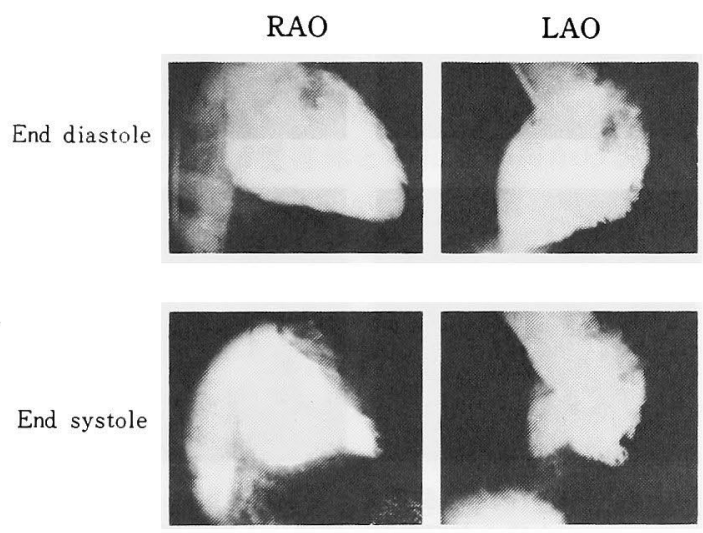

図 3 , 症例 1 . 左室造影。

入院時所見： 体温 $37.8^{\circ} \mathrm{C}$, 脈拍 $120 /$ 分整. 血 圧160/95mmHg，甲状腺右葉下部に軽度の王痛あ り, 頝静脈怒張なく, 胸部理学的所見では, 心基 部で, Levine 3/6の収縮期駆出性雑音拐よびIII 音・IV音を聴取した。肺野にラ音なく，腹部は平 坦 = 軟, 表在リンパ節を触知せず，手指に振戦を 認めた。

入院時検査所見：表 1 の上5に, 白血球数 $10200 / \mathrm{mm}^{3}$, LDH 254単位 (100 225) CPK 85単 位と軽度上昇を認め, さらに血沈亢進, CRP 6+. フィブリノーゲン $657 \mathrm{mg} / \mathrm{dl}$ と高值を示した。甲状 腺機能検査では, $\mathrm{T}_{3} 240 \mathrm{ng} / \mathrm{dl}, \mathrm{T}_{4} 17.2 \mu \mathrm{g} / \mathrm{dl}$ と高
Case 1

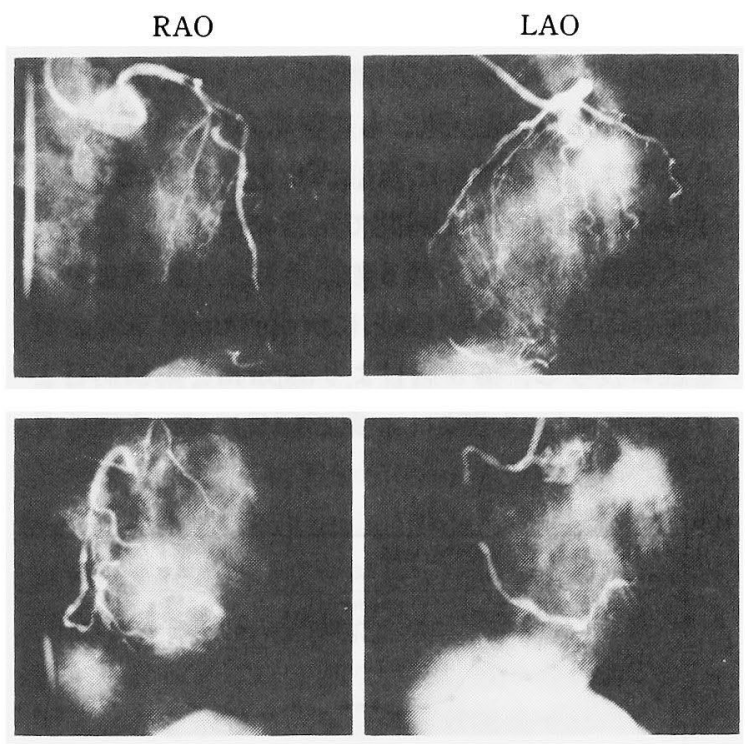

図 4, 症例 1。冠動脈造影

上段：左冠動脈，下段：右冠動脈

Case 2 K.N.

$57,10,25$

57. 12.27
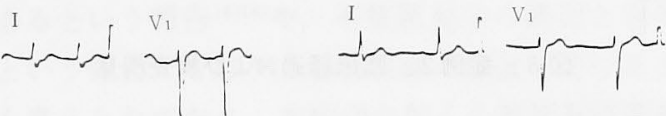

II r

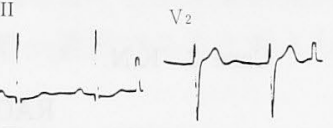

III
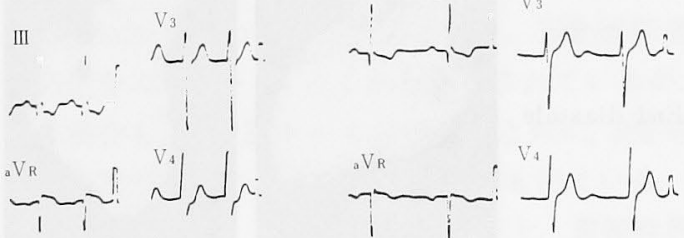

${ }^{\mathrm{V}_{\mathrm{L}}}$
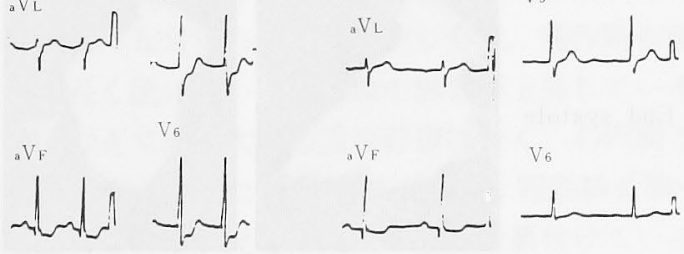

図 5, 症例 2, の心電図変化 
值を示し, 第 5 病日の $\mathrm{TSH}$ 值は $1.4 \mu \mathrm{U} / \mathrm{ml}$ と低下 していた。また第10病日に行なわれた甲状腺 ${ }^{123} \mathrm{I}$ 摄取率では $1.8 \%$ と著明に低下していた。入院時胸 部 X線像では，心・肺ともに異常なく，心電図(図 5 ) では, 入院時, II, III, $a V_{F}, V_{4} \sim V_{6}$ にST低下 が見られたが，約 1 週間で正常に復した。

入院後の経過：図6のように，入院時より， 酸素, ISDNを投与, さらにpropranolol $60 \mathrm{mg} /$ 日 を経口投与し，第 5 病日ょり aspirinを第14病日よ り prednisolonを開始し，第25病日には，炎症所見

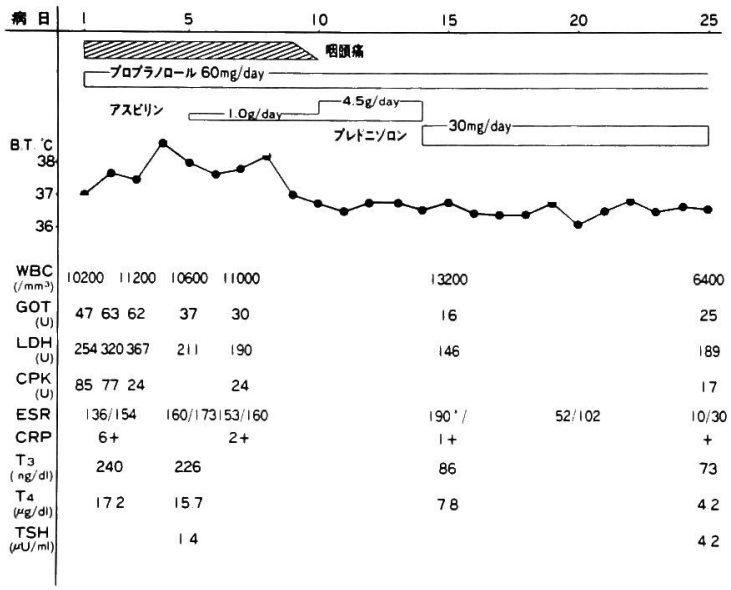

図6，症例 2 ，臨床経過および検查所見

Case 2 K.N.

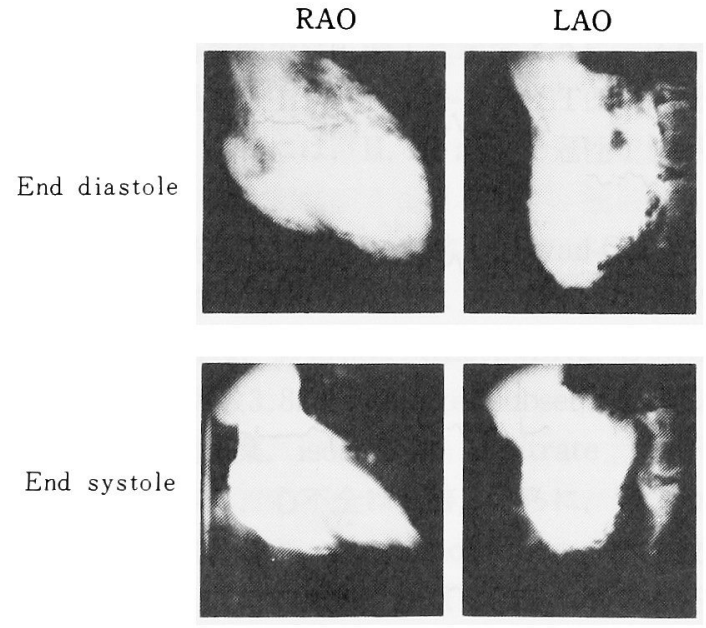

図 7, 症例 2, 左室造影

もほぼ正常化した。

約 7 週間後に行なつた左室造影（図 7 ）では, Seg. 5掞よびSeg. 7がakinesisであり, 冠動脈造影 （図 8 ）では，左冠動脈主幹部から左前下行枝Seg. 8 扣よび回旋枝Seg. 12迄強い石灰化を認め, 右冠 動脈のSeg. 2, Seg, 4に99\%, 左前下行枝Seg. 9, 回旋枝Seg. 12に75\%の狭窄を認めた。また, ${ }^{201} \mathrm{Tl}$ 心筋シンチによるEmission CT (図 9 ) では, 安

Case 2 K.N.

$\mathrm{RAO}$
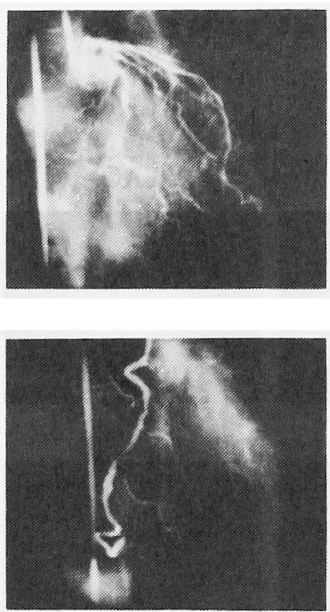

図 8. 症例 2。冠動脈造影 上段：左冠動脈，下段：右冠動脈

Case 2 K.N.

stress image redistribution image
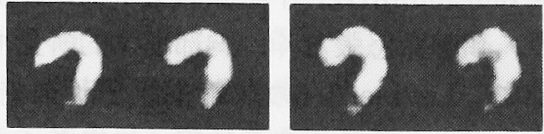

Sagittal
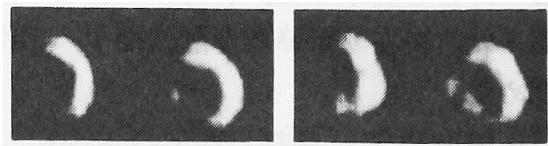

Coronal
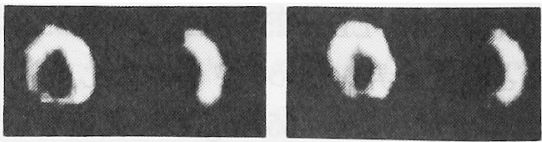

図 9. ${ }^{201} \mathrm{Tl}$ 心筋シンチによる emission CT 
静時再分布像での左室下壁の欠損像および同部位 において, 運動負荷像での欠損の増強が認められ た。

\section{考案}

垔急性甲状腺炎では，甲状腺組織の资症性破壊 のため，血中に多量の甲状腺ホルモンが流入する ことにより循環動態に変化を来す1．過剩の甲状 腺ホルモンの心血管系への作用として，1）酸素利 用および組織酸素消費量の増大に伴ら心拍出量の 増加, 2) ミトコンドリアの高エネルギーリン酸結 合形成，3）細胞内特にミトコンドリア内での高分 子（蛋白）合成，4）心筋のadenyl cyclase活性の 増加，5）cathecholamineに対する心筋感受性の 増加, 等の機序が考克られている2!.しかし，一方 では，甲状腺機能元進症患者や，甲状腺ホルモン 投与動物での心筋内 adenyl cyclaseの増加は認め られないという報告3)や，cathecholamine反応性 の充進の機序を $\beta$ 受容体との相互作用から説明し ようとする意見45)などがあり。な怙明らかでな い，前述の如く，亜急性甲状腺炎に急性心筋梗塞 を併発したという報告は我々の調べた限りでは， 見当らないが，一方甲状腺機能元進症に狭心症を 合併する頻度は, Silverら によれば5\%,宮原7ら によれば $3 \%$ 程度であり，心筋梗塞を合併するこ とは，比較的末れである，Kotlerらは甲状腺機能 元進症と心筋梗塞の合併例21例報告している が8)，その中で，冠動脈閉塞の病因として，次の三 つの機序をあげている.1）冠動脈の硬化性病変の 存在，2）冠動脈の塞栓，3）冠動脈の直接損傷, 彼らの21例中12例は, 冠動脈の硬化性病変の存在 した症例であり，残りの 9 例は，心房細動，らつ 血性心不全に起因する冠動脈塞栓症および，冠動 脈硬化性病変の既往なく，又その後の剖検あるい は冠動脈造影にて明らかな病変の認められなかつ た症例である。我々の症例は，2 例共に高度な冠 動脈の硬化性病変を有しており, Kotlerらの機序 の中では，最も頻度の高いものであつた，冠動脈 の直接損傷という機序に関して，冠動脈のSpasm が考えられ, Proskeyら ${ }^{9)}$, Bhasin ${ }^{10)} は$, 冠動脈 疾患の既往のない症例に対する病因の一つにあげ
ているが，甲状腺ホルモンとの関連については不 明である。

甲状腺ホルモンが過剩に存在すると, 組織の酸 素消費量が増大し, さらにcathecholamine反応性 の六進により，心笳の収縮力増強，心拍数増加， 末梢抵抗の低下等，いわゆる，hyperdynamic stateとなる.心の仕事量の増大は, 冠血流量の増 加で補なわれるが，これら相対的酸素欠乏状態揖 よび力学的負荷状態は, 冠動脈硬化の進んだ患者 にとつて虚血性心疾患発症の誘因となると考克ら れる。をた，甲状腺ホルモンによる直接的な inotropic $\cdot$ chronotropic effect $と$ 二次的な交感神 経系の機能立進状態に対し $\tau$, propranolol等の $\beta$ 受容体庶断薬は，実験的にも，臨床的にも効果の

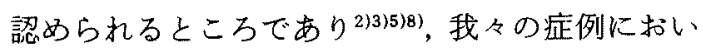
ても著効を示した，亜急性甲状腺炎では，ステロ イド薬が適応となるが, 満間ら ${ }^{22}$, 高田ら ${ }^{13)}$ はステ ロイド投与は，本症の経過・検査成績，特に血中 $\mathrm{T}_{3}, \mathrm{~T}_{4}$ 值, 甲状腺 ${ }^{131} \mathrm{I}$ 摄取率には, 明らかな影響を 及ぼさないと報告している。すた，急性心㬳梗塞 に対するステロイド薬投与の効果は, Barzilai ら ${ }^{14)}$ は, mortalityの減少をあげているが，無効で

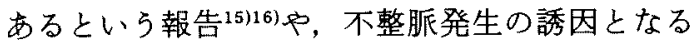
といら報告 ${ }^{17)}$ もあり，心筋組織の修復を妨げると む考之られており，本症例の如く心筋梗塞併発例 では， $\beta$ 受容体庶断薬が第一選択であると考えら れる。

又，甲状腺機能低下症の患者の治療に括いて， 甲状腺ホルモンの投与が誘因となり，冠動脈疾患 の発生をみることが, 古くから示摘されているが, この場合も, 甲状腺ホルモンの減量と共に, $\beta$ 受容 体庶断薬が有効であるとする文献 ${ }^{18)}$ 出ている。

我々の症例は， 2 例共に，心電図上，貫壁性梗 塞の所見は認められなかつたが，心電図でST，T の变化が 5 日から 1 週間持続した点, 発作時の胸 痛が長く続いている点，血中酵素が上昇している 点, 加亲て心㹡大, 心膜液眝留はなく，心内膜下 梗塞と考えられた.さらに左室造影, 冠動脈造影・ 心筋シンチの所見る，上記の診断を裏付けている と考えられた。これらは定型的な貫壁性梗塞の形 
をとらず，梗塞の範囲もより小規模と考えられる が, Cheahらの報告 ${ }^{19)}$ で，甲状腺機能六進症との合 併例では，心㬳梗塞としては，非定型的な例も多 く存在すると述べているのに，あてはをると思わ れる。この理由は，明らかではないが，我々の症 例のように基礎に重篤な冠動脈硬化症があり，亜 急性甲状腺による急激な血行動態の変化，心䇗酸 素需要の増加が加わつたため, 心筋梗塞が発症し たものであるが，このような場合，冠動脈の閉塞 よりは酸素の需要供給のアンバランスと, 硬化性 病变を有する冠動脈支配領域の血流低下との相乗 効果により心筇虚血が起こると考兄られ，梗塞も， より末梢領域の心内膜下が多いのではないかと考 学られた。

\section{結語}

典型的な亜急性甲状腺炎と同時に，急性心内膜 下梗塞を併発した 2 例を経験したので若干の文献 的考察を加克て報告した。

\section{文献}

1) 満間照典：Subacute thyroiditis. 日本臨床 38 : 1716, 1980 .

2) De Groot GS: Thyroid and the heart. Mayo Clin Proc 47: 864, 1972

3) Levey GS: Cathecholamine sensitivity, thyroid hormone and the heart. Amer J Med $50: 413,1971$.

4) Howitt $G$, et al: Beta-sympathetic blockade in hyperthyroidism. Lancet $1: 628,1966$.

5) Fisherman $W$, et al: Clinical pharmacology of the new beta-adrenergic blocking drugs. Part 3. Amer Heart J 98: 119, 1979.

6) Sliver $\mathrm{S}$, et al: The treatment of thyrocardiac disease with radioactive iodine. Prog Car diovasl Dis $5: 64,1962$.

7) 宮原光夫, 他：バセドウ病の循環器症状とその病 態生理。日本臨床 $29: 1303,1971$.

8) Kotlar MN, et al: Sudden death associated with thyroid normone abuse. Amer J Med 71 : 887, 1981.

9) Proskey $\mathrm{AJ}$, et al: Myocardial infarction associated with thyrotoxicosis. Chest $72: 109$, 1977.

10) Bhasin $\mathrm{S}$, et al: Myocardial infarction as sociated with thyrotoxicosis. Arch Intern Med 132: 723, 1973.

11) Cheiltlin MD, et al: Myocardial infarction without athelosclerosis. JAMA $231: 951,1975$.

12）満間照典，他：亜急性甲状腺炎にアスピリン又は プレドニゾロン治㞠中の末梢甲状腺ホルモンの変 動。最新医学 $32: 330,1977$.

13）高田一太郎, 他：要急性甲状腺炎71例の臨床的検 討. 北里医学 $11: 214,1981$.

14) Barziliai $D$, et al: Use of hydrocortisone in the treatment of acute myocardial infarction. Chest $61: 488,1972$

15) Peters RW, et al: Effect of therapy with methylprednisolone on the size of myocardial infarcts in man. Chest $73: 483,1976$.

16) Madias JE, et al: Effect of methylprednisolone on the ischemic damage in patients with acute myocardial infarction. Circulation 65 : 1106, 1982 .

17) Roberts R, et al: Deleterious effect of methylprednisolone in patients with myocardial in farction. Circulation 53(Suppl I) : I-204, 1976.

18) Leading Article. Management of angina and hypothyroidism. Brit Med J 282 : 1818, 1981.

19) Cheah JS, et al: Myocardial infarction in thyrotoxicosis. Med J Aust 1:393, 1971. 